\title{
PENGARUH STRATEGI PEMBELAJARAN \\ DAN GAYA BELAJAR TERHADAP HASIL BELAJAR PENDIDIKAN KEWARGANEGARAAN
}

\author{
Oleh: Etin Solihatin*
}

\begin{abstract}
With regards to findings of the study, it can be concluded that in general, (1) the use of Cooperative Learning strategy has given higher achievement in learning Civics than that of Expository one; (2) the use of Cooperative Learning strategy with learners of field independent learning style has effect in the form of higher achievement in learning Civics than that of Expository one; (3) the use of Cooperative Learning strategy with learners of field dependent learning style has effect in the form of lower achievement in learning Civics than that of Expository one; and (4) there is interaction between the use of learning strategy and learner's learning style on learner's achievement in learning Civics.
\end{abstract}

Key Words: Learning strategy, learning style, civics learning achievement.

\section{PENDAHULUAN}

\section{Latar Belakang Masalah}

Pola pembelajaran PKn menekankan pada unsur pendidikan dan pembekalan pada peserta didik. Penekanan pembelajaran bukan sebatas pada upaya mencekoki dan menjejali peserta didik dengan sejumlah konsep yang bersifat hapalan belaka, seperti yang sering dilakukan oleh pendidik, dengan mengabaikan gaya belajar peserta didik yang masing-masing berbeda. Melainkan terletak pada upaya agar peserta didik mampu menjadikan apa yang telah dipelajari sebagai bekal dalam memahami, dan ikut serta dalam melakoni kehidupan masyarakat lingkungannya, serta sebagai bekal untuk melanjutkan pendidikan ke jenjang yang lebih tinggi. Di sinilah sebenarnya penekanan misi dari pendidikan
PKn. Hal ini sejalan dengan misi pendidikan nasional yang ketiga yaitu: meningkatkan kesiapan masukan dan kualitas proses pendidikan untuk mengoptimalkan pembentukan kepribadian yang bermoral (Sisdiknas No. 20 tahun 2003).

Menurut A. Suhaenah Suparno seperti yang dikutip Andreas Harefa (2001:127) bahwa pengajar yang profesional harus menguasai kompetensi global seperti penguasaan internet sebagai media belajar, untuk mengakses informasi dan pengetahuan mutakhir yang relevan dengan tugas dan tanggung jawabnya sebagai pengajar dan pendidik sejati.

Kondisi seperti inipun ditemukan dalam pembelajaran PKn di SMP Negeri I Jatisari, yaitu pendidik lebih mendominasi dalam proses pembelajaran (teacher 


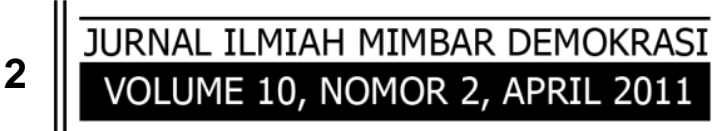

centered), kurang melibatkan peserta didik dalam proses pembelajaran, sehingga dalam pembelajaran cenderung pasif. Padahal setiap peserta didik memiliki gaya belajar yang berbeda.

Atas dasar asumsi di atas, mungkin pendidik sudah merasa mengajar dengan baik, tetapi peserta didik tidak belajar. Hal ini berdampak pada perolehan hasil belajar PKn peserta didik dengan rata-rata 68, sedangkan nilai KKM 70.

Sehubungan dengan permasalahan di atas, maka upaya peningkatan kualitas proses pembelajaran dalam PKn merupakan suatu kebutuhan yang sangat mendesak untuk dilakukan. Jenis strategi pembelajaran seperti apa yang dapat diduga mempengaruhi hasil belajar? Terdapat berbagai strategi pembelajaran yang saat ini berkembang dalam bidang pendidikan, namun yang akan dikaji dalam penelitian ini adalah strategi pembelajaran cooperative learning berdasarkan prinsip pembelajaran yang berpusat pada peserta didik. Sedangkan ekspositori cenderung menekankan pada penyampaian informasi yang bersumber dari buku teks, dan peran pendidik menjadi lebih dominan.

Selain faktor strategi pembelajaran, pencapaian hasil belajar juga ditentukan oleh karakteristik peserta didik. Salah satu faktor yang perlu dipertimbangkan dalam pembelajaran adalah gaya belajar. Witkin (1981:137-138) mengadakan penelusuran perbedaan karakteristik persepsi manusia yang terbagi dalam dua tipe yaitu (1) field independent dan (2) field dependent, perbedaan tersebut terletak pada waktu yang digunakan untuk menyelesaikan tugas dan tingkat kesukaran soal-soal yang dikerjakan oleh peserta didik. Gaya belajar ini perlu untuk diketahui oleh pendidik, agar dapat menciptakan kondisi pembelajaran yang kondusif.

Memperhatikan berbagai faktor yang diduga dapat mempengaruhi hasil belajar PKn, maka faktor strategi pembelajaran dengan memperhatikan gaya belajar merupakan faktor yang penting untuk dikaji dalam penelitian ini.

\section{Perumusan Masalah}

Permasalahan dalam penelitian ini dirumuskan sebagai berikut:

(1) Secara keseluruhan, apakah terdapat perbedaan hasil belajar PKn antara peserta didik yang mendapatkan strategi pembelajaran Cooperative Learning dan peserta didik yang mendapatkan strategi pembelajaran Ekspositori?

(2) Untuk peserta didik yang memiliki gaya belajar field independent, apakah terdapat perbedaan hasil belajar PKn antara peserta didik yang mendapatkan strategi pembelajaran Cooperative Learning dan peserta didik yang mendapatkan strategi pembelajaran ekspositori? 
(3) Untuk peserta didik yang memiliki gaya belajar field dependent, apakah terdapat perbedaan hasil belajar PKn antara peserta didik yang mendapatkan strategi pembelajaran Cooperative Learning dan peserta didik yang mendapatkan strategi pembelajaran ekspositori?

(4) Apakah terdapat pengaruh interaksi antara strategi pembelajaran dengan gaya belajar terhadap hasil belajar PKn?

\section{Manfaat Penelitian}

Hasil penelitian ini diharapkan bermanfaat untuk meningkatkan hasil belajar PKn, melalui strategi pembelajaran Cooperative Learning dengan memperhatikan gaya belajar peserta didik.

Manfaat praktis temuan penelitian ini dapat dijadikan bahan rujukan dan pertimbangan bagi para pengambil keputusan di lingkungan Kementerian Pendidikan Nasional, khususnya para penyelenggara di SMPN Jatisari Kabupaten Karawang, guna mengambil keputusan untuk meninjau dan memberi kewenangan kepada pendidik untuk menerapkan strategi pembelajaran Cooperative Learning dengan memperhatikan gaya belajar dalam rangka meningkatkan hasil belajar PKn.

\section{KERANGKA TEORETIK DAN}

\section{PENGAJUAN HIPOTESIS}

\section{Deskripsi Teoretik}

\section{Belajar dan Pembelajaran}

Meyer dalam Charles M. Reigeluth mengemukakan pengertian belajar telah berkembang dalam tiga pandangan. Pertama, belajar telah terjadi ketika peserta didik memperkuat atau memperlemah hubungan antara stimulus dan respons. Kedua, belajar sebagai penambahan pengetahuan. Hal ini didasarkan pada ide bahwa belajar terjadi ketika peserta didik menempatkan informasi dalam long-term memory. Ketiga, belajar sebagai mengkonstruksi pengetahuan. Hal ini didasarkan pada ide bahwa belajar terjadi ketika peserta didik aktif mengkonstruksi pengetahuan (Charles M. Reigeluth, 1999:143).

Menurut Gradler bahwa belajar adalah proses seseorang memperoleh berbagai kecakapan, keterampilan, dan sikap. Belajar adalah perubahan dalam disposisi manusia atau kapabilitas yang dicapai selama waktu tertentu dan tidak semata-mata disebabkan oleh proses pertumbuhan. Perubahan tersebut merupakan perubahan tingkah laku manusia yang dapat diinferensikan dengan membandingkan tingkah laku manusia yang dapat diinferensikan dengan membanding- 
$4 \quad \begin{aligned} & \text { JURNAL ILMIAH MIMBAR DEMOKRASI } \\ & \text { VOLUME 10, NOMOR 2, APRIL } 2011\end{aligned}$

kan tingkah laku sebelum dikondisikan dalam situasi belajar dengan tingkah laku yang ditujukan setelah adanya perlakuan (Margareth E. Bell, Gredler, 1991: 188189).

Menurut Undang-undang No. 20 tahun 2003, Pasal 1 bahwa pembelajaran adalah proses interaksi peserta didik dengan pendidik dan sumber belajar pada suatu lingkungan belajar. Romiszowski mengemukakan bahwa pembelajaran adalah suatu perangkat kegiatan yang mempengaruhi orang yang belajar sedemikian rupa sehingga terjadinya proses pembelajaran (AJ Romiszowski, 1981: 110126).

Berdasarkan uraian-uraian di atas, maka terdapat empat hal yang penting dalam belajar yakni : (1) belajar merupakan suatu proses perubahan tingkah laku akibat pengalaman/latihan yang dilakukan secara sadar (2) perubahan dalam belajar bukan bersifat sementara (relatif menetap), (3) belajar merupakan perubahan tingkah laku yang bersifat positif dan memberikan manfaat bagi individu (4) belajar merupakan perubahan yang terarah dalam mencapai tujuan tertentu. Sedangkan yang dimaksud dengan pembelajaran (instruction) adalah usaha untuk mengelola lingkungan dengan memanfaatkan aneka sumber belajar dengan sengaja agar seseorang membentuk diri secara positif tertentu dalam kondisi tertentu.

\section{Hasil Belajar PKn}

Gagne, Briggs dan Wager mengemukakan bahwa hasil belajar dapat diamati melalui kinerja peserta didik. Terdapat lima jenis hasil belajar yaitu (1) keterampilan intelektual, yakni suatu kemampuan membuat seseorang menjadi kompeten terhadap suatu subjek, sehingga mereka dapat mengelompokkan, mengidentifikasi, mendemonstrasikan dan menggeneralisasikan suatu gejala, (2) strategi kognitif, yaitu kemampuan seseorang untuk dapat mengontrol aktivitas intelektualnya dalam mengatasi masalah yang dihadapi orang tersebut, (3) informasi verbal, yaitu kemampuan seseorang untuk menggunakan bahasa lisan maupun bahasa tulisan dalam mengungkap suatu masalah, (4) sikap yaitu kecenderungan untuk menerima atau menolak suatu objek, (5) keterampilan motorik, yaitu kemampuan seseorang untuk mengkoordinasikan gerakan otot secara teratur dan lancar dalam keadaan sadar (Robert M. Gagne, Leslie J. Briggs dan Walter W. Wager, 1999: 24-30).

Reigeluth mengemukakan bahwa hasil pembelajaran secara umum dapat dikategorisasi menjadi tiga indikator, yaitu (1) efektivitas pembelajaran yang biasanya 
diukur dari tingkat keberhasilan peserta didik dari berbagai sudut, (2) efisiensi pembelajaran, yang biasanya diukur dari waktu belajar dan atau biaya pembelajaran, dan (3) daya tarik pembelajaran yang selalu diukur dari tendensi peserta didik ingin belajar secara terus menerus (Charles Reigeluth, 1983: 36-52).

\section{Strategi Pembelajaran}

Menurut Seels dan Richey, strategi pembelajaran adalah sebagai spesifikasi untuk memilih dan mengurutkan kejadian dan aktivitas dalam pembelajaran (Barbara B. Seels and Rita C. Richey, 1994:31). Briggs mengatakan strategi pembelajaran berkaitan dengan penentuan urutan yang memungkinkan tercapainya tujuan-tujuan dan memutuskan bagaimana untuk menerapkan kegiatan-kegiatan instruksional bagi masing-masing individu (peserta didik) (Robert M. Gagne, etc, 1999: 20-25). Strategi pembelajaran adalah pendekatan menyeluruh pembelajaran dalam suatu sistem pembelajaran, yang berupa pedoman umum dan kerangka kegiatan untuk mencapai tujuan umum pembelajaran yang dijabarkan dari pandangan falsafah atau teori belajar tertentu (Yusufhadi Miarso, 2005: 530).

Dalam penelitian ini yang dimaksudkan dengan strategi pembelajaran adalah pendekatan menyeluruh dalam suatu sistem pembelajaran, yang berupa pedoman umum dan kerangka kegiatan untuk mencapai tujuan umum pembelajaran, yang melukiskan prosedur yang sistematis dalam membantu usaha belajar peserta didik, mengorganisasi pengalaman belajar, mengatur, merencanakan bahan ajar untuk mencapai tujuan pembelajaran. Dalam penelitian ini akan dikaji dua strategi pembelajaran yaitu strategi pembelajaran Cooperative Learning dan Ekspositori (Expository Learning).

\section{Strategi Pembelajaran Cooperative Learning}

Arends mengemukakan bahwa strategi pembelajaran Cooperative Learning adalah strategi pembelajaran yang berdasarkan prinsip pembelajaran yang berpusat pada peserta didik (learnercentered principles of learning) (Richards J. Arens, 1998:223). Stahl mengemukakan ciri-ciri pembelajaran Cooperative Learning adalah : (1) belajar bersama teman, (2) terjadi tatap muka dengan teman, (3) saling mendengar pendapat teman, (4) produktif berbicara, keputusan tergantung pada peserta didik sendiri, (5) peserta didik dapat aktif dalam belajar (Robert J. Stahl, 1994: 19). Selanjutnya Stahl (1994:10-15) mengemukakan beberapa konsep mendasar yang perlu diperhatikan dan diupayakan oleh pendidik dalam menggunakan strategi Cooperative Learning di kelas yakni 
sebagai berikut: (1) kejelasan rumusan tujuan pembelajaran 2) penerimaan yang menyeluruh oleh peserta didik tentang tujuan belajar 3) ketergantungan yang bersifat positif 4) keterbukaan dalam interaksi pembelajaran 5) tanggung jawab individu 6) pengakuan dan penghargaan kelompok yang sukses 7) heterogenitas kelompok 8) sikap dan perilaku sosial yang positif 9) debriefing (refleksi dan internalisasi) 10) kepuasan dalam belajar.

Berdasarkan berbagai pendapat di atas yang dimaksud dengan strategi pembelajaran Cooperative Learning dalam penelitian ini adalah strategi pembelajaran yang lebih menekankan pada kerjasama antar peserta didik dalam kelompok belajar, sehingga diharapkan dapat mewujudkan tujuan belajar yang telah ditetapkan.

\section{Strategi Pembelajaran Ekspositori}

Romiszowski berpendapat bahwa strategi pembelajaran ekspositori didasarkan pada teori pemrosesan informasi. Strategi ini erat kaitannya dengan pendekatan deduktif di mana metode ini dimulai dengan penyajian informasi mengenai prinsip atau kaidah kemudian diikuti dengan tes penguasaan, penerapan dalam bentuk contoh dan penerapan pada situasi tertentu (AJ. Romiszowski, 1981: 292-293).

Dalam penelitian ini yang dimaksud dengan strategi pembelajaran ekspositori adalah strategi pembelajaran yang menekankan pada proses deduktif, pembelajaran yang didasarkan pada proses meaningful reception learning. Strategi ini cenderung menekankan penyampaian informasi atau pengalaman pribadi dengan menggunakan teknik ceramah, demonstrasi dan laporan studi.

\section{Gaya Belajar}

Witkin (1981:137-138) mengadakan penelusuran perbedaan karakteristik persepsi manusia yang terbagi dalam dua tipe yaitu (1) Field Independent dan (2) Field Dependent, perbedaan tersebut terletak pada waktu yang digunakan untuk menyelesaikan tugas dan tingkat kesukaran soal-soal yang dikerjakan oleh peserta didik.

Gaya belajar field independent memiliki ciri, seperti yang dinyatakan oleh Witkin (1981: 137-138) bahwa gaya belajar field independent memiliki ciri-ciri lebih mampu melihat bagian-bagian yang membentuk suatu pola dasar, lebih menyukai pekerjaan dengan angka-angka, sain dan tugas pemecahan masalah. Senada dengan pendapat di atas Klausmeier (1985:135) mengemukakan ciri gaya belajar field independent adalah (1) dapat memberikan interpretasi dan dapat menyusun kembali situasi lingkungan (2) kurang tertarik pada hal-hal sosial, mereka lebih suka bekerja dengan prinsip dan ideide yang abstrak (3) bila dilihat dari sudut 
minat pelajaran lebih tertarik pada ilmu pasti (4) cenderung mengatur sendiri tujuan belajarnya dan mereka mengutamakan penguatan dari dalam dirinya sendiri.

Gaya belajar field dependent diartikan sebagai ketergantungan medan adalah bergantung pada isyarat medan visual dalam eksperimen-eksperimen gaya ruang (CP Chaplin, 1989: 91). Gaya belajar field dependent memiliki beberapa ciri, seperti yang dinyatakan oleh Witkin bahwa gaya belajar field dependent memiliki ciriciri: cenderung melihat pola-pola sebagai sesuatu keseluruhan dan sulit memisahkan aspek-aspek situasi atau pola, cenderung berorientasi ke arah hubungan manusia dan sosial, cenderung pola informasi sosial seperti percakapan dan hubungan, suka kerja kelompok dan menyukai mata pelajaran sejarah dan sastra.

Atas dasar kajian teori di atas, maka yang dimaksud gaya belajar field independent dalam penelitian ini adalah gaya belajar yang bergantung pada isyaratisyarat tubuh dan kecenderungan seseorang untuk menggantungkan penilaian persepsi pada isyarat-isyarat dari dalam dirinya sendiri dan memiliki ciri-ciri sebagai berikut: (1) keinginan mengerjakan sesuatu atas dorongan dari dalam dirinya sendiri, (2) lebih percaya diri dan mandiri (3) dapat menginterpretasikan dan menyusun kembali situasi stimulus (4) lebih tertarik pada pelajaran-pelajaran ilmu pasti (5) lebih suka dengan prinsip dan ide-ide abstrak (6) melihat sesuatu secara analitik.

Dari kajian berbagai teori di atas, maka dalam penelitian ini yang dimaksud dengan gaya belajar field dependent adalah gaya yang bergantung pada isyarat-isyarat medan visual yang merupakan kecenderungan seseorang menggantungkan penilaian persepsi pada isyarat-isyarat dari luar dirinya sendiri yang memiliki ciri-ciri sebagai berikut: (1) keinginan mengerjakan sesuatu atas dorongan orang lain (2) suka bekerja sama dengan orang lain (3) menerima situasi stimulus sebagaimana adanya (4) lebih tertarik pada pelajaranpelajaran ilmu sosial (5) kurang dapat bekerja dengan konsep yang abstrak (6) melihat sesuatu secara global.

\section{Hasil Penelitian yang Relevan}

\section{Hasil Penelitian Mengenai Gaya Belajar}

Menurut basil berbagai penelitian, gaya belajar peserta didik mempengaruhi basil belajarnya. Hasil penelitian Degeng dan Sukaryana menyimpulkan bahwa peserta didik yang memiliki gaya kognitif "Field Independent" lebih unggul daripada peserta didik yang bergaya kognitif "Field dependent" dalam perolehan belajar. Retensi mata pelajaran juga lebih banyak dapat dipertahankan oleh peserta didik yang bergaya kognitif "Field independent" dari pada peserta didik yang bergaya kognitif 
"Field dependent" (I Nyoman Sudana, 1994:32)

\section{Hasil Penelitian Mengenai Model Cooperative Learning}

Van Sickle dalam penelitiannya mengenai model Cooperative learning dan implikasinya terhadap perolehan belajar peserta didik dan pengembangan kurikulum social studies, menemukan bahwa sistem belajar kelompok dan dibriefing secara individual dan kelompok dalam model cooperative learning mendorong tumbuhnya tanggung jawab sosial dan individual peserta didik, berkembangnya sikap ketergantungan yang positif, mendorong peningkatan dan kegairahan belajar peserta didik serta pengembangan dan ketercapaian kurikulum. (Rober J Stahl and Ronald L Van Sickle, 1992:95)

\section{Kerangka Berpikir}

1. Perbedaan Hasil Belajar PKn antara Peserta Didik yang Mendapatkan Strategi Pembelajaran Cooperative Learning dan yang Mendapat

Pembelajaran Eksplositori

Strategi pembelajaran Cooperative Learning dan Ekspositori merupakan strategi pembelajaran yang dapat digunakan pendidik dalam mengarahkan peserta didik untuk mencapai tujuan pembelajaran yang telah ditetapkan.
Mengacu pada konseptual dan tujuan pembelajaran PKn sebagai-mana diuraikan, dengan demikian peserta didik yang mendapatkan strategi pembelajaran Cooperative Learning dapat diduga mencapai hasil belajar PKn yang lebih tinggi daripada peserta didik yang mendapatkan strategi pembelajaran Ekspositori.

2. Perbedaan Hasil Belajar PKn Peserta Didik yang Memiliki Gaya Belajar Field Independent dan Mendapatkan Strategi Pembelajaran Cooperative Learning dengan Peserta Didik yang Mendapatkan Strategi Pembelajaran Ekspositori

Peserta didik yang memiliki gaya belajar field independent memiliki ciri-ciri sebagai berikut: (1) keinginan mengerjakan sesuatu atas dorongan dari dalam dirinya sendiri (2) lebih percaya diri dan mandiri (3) dapat menginterpretasikan dan menyusun kembali situasi stimulus (4) lebih tertarik pada pelajaran-pelajaran ilmu pasti (5) lebih suka dengan prinsip dan ide-ide abstrak (6) melihat sesuatu secara analitik.

Dengan demikian peserta didik yang memiliki gaya field independent, terdapat keyakinan dalam melaksanakan tugas dengan baik. Peserta didik memiliki rasa percaya diri dalam menghadapi tugas yang sulit dan merasa yakin terhadap kemampuannya untuk menyelesaikan permasalahan. Dalam pembelajaran 
Cooperative Learning selain memungkinkan peserta didik untuk lebih berhasil dalam belajarnya, juga memungkinkan untuk mengembangkan pengetahuan, kemampuan, keterampilan secara penuh dalam suasana terbuka dan demokratis. Lingkungan pembelajaran tersebut, bagi peserta didik yang memiliki gaya belajar field independent tidak akan merasa terhambat untuk berinteraksi dalam kelompok.

Dengan demikian dapat diduga bahwa hasil belajar PKn pada peserta didik yang memiliki field independent dan mendapat strategi pembelajaran Cooperative Learning lebih tinggi daripada yang mendapat strategi pembelajaran Ekspositori.

3. Perbedaan Hasil Belajar PKn pada Peserta Didik yang Memiliki Gaya Belajar Field Dependent dan Mendapat Strategi Pembelajaran Cooperative Learning dengan Peserta Didik yang Mendapatkan Strategi Pembelajaran Ekspositori

Peserta didik yang memiliki gaya belajar field dependent memiliki ciri-ciri sebagai berikut: (1) keinginan mengerjakan sesuatu atas dorongan orang lain (2) suka bekerja sama dengan orang lain (3) menerima situasi stimulus sebagaimana adanya (4) lebih tertarik pada pelajaranpelajaran ilmu sosial (5) kurang dapat bekerja dengan konsep yang abstrak (6) melihat sesuatu secara global.

Dengan demikian dapat diduga bahwa hasil belajar PKn pada peserta didik yang memiliki gaya belajar field dependent dan mendapatkan strategi pembelajaran Cooperative Learning lebih rendah daripada yang mendapatkan strategi pembelajaran Ekspositori.

4. Interaksi Antara Strategi Pembelajaran dengan Gaya Belajar Terhadap Hasil Belajar PKn

Pembelajaran yang menyenangkan bagi peserta didik, apabila dirasakan oleh peserta didik kenyamanan dan kesempatan berinteraksi belajar bersama dengan peserta didik lainnya. Pembelajaran yang kondusif akan terwujud, jika pendidik memperhatikan perbedaan individu peserta didik, salah satunya adalah gaya belajar. Oleh karena itu, tidak dapat dihindari dalam pengelolaan kelas, setiap pendidik dapat mempertimbangkan berbagai perbedaan peserta didik.

Dengan demikian diduga terdapat interaksi antara strategi pembelajaran dengan gaya belajar terhadap hasil belajar PKn.

\section{Perumusan Hipotesis Penelitian}

Hipotesis penelitian ini dirumuskan sebagai berikut: 
1. Secara keseluruhan hasil belajar PKn pada peserta didik yang mendapatkan strategi pembelajaran Cooperative Learning lebih tinggi daripada peserta didik yang mendapatkan strategi pembelajaran Ekspositori.

2. Hasil Belajar PKn pada peserta didik yang memiliki gaya belajar field Independent dan mendapatkan strategi pembelajaran Cooperative Learning lebih tinggi daripada peserta didik yang mendapat strategi pembelajaran Ekspositori.

3. Hasil belajar PKn pada peserta didik yang memiliki gaya belajar field dependent dan mendapatkan strategi pembelajaran Cooperative Learning lebih rendah daripada peserta didik yang mendapat strategi pembelajaran Ekspositori.

4. Ada pengaruh interaksi antara strategi pembelajaran dan gaya belajar terhadap hasil belajar PKn.

\section{METODE PENELITIAN}

\section{Tujuan Operasional Penelitian}

Secara operasional penelitian ini bertujuan untuk meningkatkan hasil belajar PKn melalui penggunaan strategi pembelajaran dan memperhatikan gaya belajar peserta didik. Secara rinci tujuan operasional penelitian ini adalah sebagai berikut:
1. Untuk mengetahui ada tidaknya perbedaan hasil belajar PKn antara peserta didik yang mendapatkan strategi pembelajaran Cooperative Learning dan peserta didik yang mendapat strategi pembelajaran Ekspositori.

2. Untuk mengetahui peserta didik yang memiliki gaya belajar field independent, apakah terdapat perbedaan hasil belajar PKn antara peserta didik yang mendapat pembelajaran strategi Cooperative Learning dan peserta didik yang mendapat strategi pembelajaran Ekspositori.

3. Untuk mengetahui peserta didik yang memiliki gaya belajar field dependent, apakah terdapat perbedaan hasil belajar PKn antara peserta didik yang mendapatkan pembelajaran strategi Cooperative Learning dan peserta didik yang mendapat strategi pembelajaran Ekspositori.

4. Untuk mengetahui ada tidaknya pengaruh interaksi antara strategi pembelajaran dengan gaya belajar terhadap hasil belajar PKn.

\section{Tempat dan Waktu Penelitian}

Penelitian ini menggunakan subyek penelitian peserta didik di SMP Negeri I Jatisari, Kecamatan Jatisari, Kabupaten Karawang Provinsi Jawa Barat. Subyek penelitian adalah peseta didik kelas VII semester 2 . 


\section{Metode dan Desain Penelitian}

Penelitian ini menggunakan metode eksperimen dengan rancangan desain faktorial 2x2 (ANAVA dua arah). Variabel yang diteliti adalah strategi pembelajaran sebagai variabel bebas dengan mempertimbangkan gaya belajar sebagai variabel atribut, dan hasil belajar sebagai variabel terikat. Faktor strategi pembelajaran (A) terdiri dari Cooperative Learning $\left(\mathrm{A}_{1}\right)$ dan Ekspositori $\left(\mathrm{A}_{2}\right)$. Sedangkan faktor gaya belajar terdiri atas field independent $\left(\mathrm{B}_{1}\right)$, dan field dependent $\left(\mathrm{B}_{2}\right)$.

\begin{tabular}{|l|c|c|}
\hline \multirow{2}{*}{ Variabel Perlakuan (A) } & \multicolumn{2}{|c|}{ Strategi Pembelajaran } \\
\cline { 2 - 3 } & Cooperative $\left(\mathrm{A}_{1}\right)$ & Ekspositori $\left(\mathrm{A}_{2}\right)$ \\
\hline Field independent $\left(\mathrm{B}_{1}\right)$ & $\mathrm{A}_{1} \mathrm{~B}_{1}$ & $\mathrm{~A}_{2} \mathrm{~B}_{1}$ \\
\hline Field dependent $\left(\mathrm{B}_{2}\right)$ & $\mathrm{A}_{1} \mathrm{~B}_{2}$ & $\mathrm{~A}_{2} \mathrm{~B}_{2}$ \\
\hline
\end{tabular}

\section{Populasi dan Teknik Pengambilan Sampel}

Populasi target penelitian in adalah seluruh peserta didik di SMPN Kabupaten Karawang Provinsi Jawa Barat. Populasi terjangkau dalam penelitian ini adalah peserta didik di SMPN Kelas VII semester II Kecamatan Jatisari Kabupaten Karawang Provinsi Jawa Barat.

Teknik pengambilan sampel dilakukan dengan cara sebagai berikut: (1) menentukan secara acak dengan undian salah satu wilayah SMPN yang berada di Kabupaten Karawang. Dalam hal ini diperoleh SMPN yang berada di Kecamatan Jatisari, (2) Menentukan secara acak dengan undian, SMPN yang akan dijadikan tempat pelaksanaan penelitian. Dalam hal ini diperoleh SMPN I Jatisari, (3) Menentukan secara acak 1 kelas untuk pelaksanaan pembelajaran Cooperative Learning dan pelaksanaan pembelajaran Ekspositori. Dari hasil undian diperoleh peserta didik kelas VII C untuk perlakuan dengan menggunakan strategi pembelajaran Cooperative Learning dan kelas VII A untuk kelas kontrol dengan menggunakan strategi pembelajaran Ekspositori. (4) Menentukan subyek penelitian, dengan cara yaitu semua peserta didik diberikan instrumen gaya belajar dan dilanjutkan dengan perhitungan terhadap hasil jawaban. Untuk keperluan analisis data penelitian, maka dari kelompok percobaan maupun kontrol diambil $27 \%$ peserta didik dengan gaya belajar field independent, dan $27 \%$ peserta didik untuk gaya belajar field dependent.

\section{Teknik Pengumpulan Data}

Alat pengumpul data yang digunakan adalah tes dan angket. Tes digunakan untuk mengumpulkan data hasil 


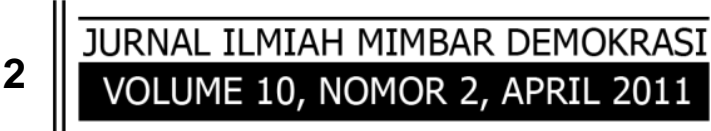

belajar PKn, sedangkan angket untuk mengumpulkan data gaya belajar.

Pengujian validitas butir instrumen tes hasil belajar PKn menggunakan rumus point biserial. Kriteria suatu butir instrumen dikategorikan valid apabila koefisien korelasi point biserial antara skor butir dengan skor total lebih besar. Hasil perhitungan validitas butir pada taraf signifikansi $\alpha=0,05$ dan $\mathrm{n}=30, \mathrm{r}_{\text {tabel }}=$ 0,361, maka 35 butir tes dinyatakan valid, karena $r_{\text {hitung }}>r_{\text {tabel }}$. Sedangkan 5 butir tes yaitu nomor: 3, 13, 21, 29, 39 dinyatakan tidak valid (didrop).

Pengujian reliabilitas tes hasil belajar PKn menggunakan rumus KR-20, diperoleh koefisien reliabilitas tes hasil belajar PKn sebesar 0,959. Berdasarkan nilai koefisien ini maka disimpulkan bahwa tes hasil belajar PKn yang digunakan memiliki tingkat reliabilitas yang sangat tinggi. Dalam hal ini sesuai yang direkomendasikan bahwa koefisien reliabilitas tes yang baik adalah berada sekitar 0,80 atau sekitar 0,90. Dengan demikian instrumen tes hasil belajar PKn dapat digunakan untuk penelitian selanjutnya.

Pengujian validitas butir instrumen gaya belajar dihitung dengan korelasi Product Moment dari Pearson, yakni mengkorelasikan skor setiap butir dengan skor pada perangkat skala atau skor total. Hasil perhitungan validitas butir pada taraf signifikan $\alpha=0,05$ dan $\mathrm{n}=30$, serta $\mathrm{r}_{\text {tabel }}=$ $0,261 \mathrm{~m}$ maka 36 butir instrumen gaya belajar dinyatakan valid, karena $\mathrm{r}_{\text {hitung }}>$ $\mathrm{r}_{\text {tabel. }}$ Sedangkan 4 butir dinyatakan tidak valid (didrop), karena $r_{\text {hitung }}<r_{\text {tabel }}$. Adapun butir instrumen gaya belajar yang didrop yaitu nomor : 16, 24, 35, 39.

$$
\text { Pengujian reliabilitas butir }
$$
instrumen gaya belajar menggunakan rumus KR-20 diperoleh koefisien reliabilitas instrumen gaya belajar sebesar 0,941. Berdasarkan nilai koefisien ini maka disimpulkan bahwa instrumen gaya belajar memiliki tingkat reliabilitas yang sangat tinggi. Dalam hal ini sesuai yang direkomendasikan bahwa koefisien reliabilitas yang baik berada di sekitar 0,80 atau sekitar 0,90. Dengan demikian instrumen tersebut dapat digunakan untuk penelitian selanjutnya.

\section{Teknik Analisis Data}

Untuk menguji hipotesis penelitian yang digunakan, menggunakan analisis varians (ANAVA) dua jalur yang dilanjutkan dengan uji Tukey untuk mengetahui perbedaan rata-rata hasil belajar PKn.

\section{HASIL PENELITIAN}

\section{Deskripsi Data}

Deskripsi hasil belajar PKn peserta dibagi ke dalam enam kelompok berdasarkan strategi pembelajaran (Cooperative Learning dan Ekspositori) dan 
gaya belajar (field independent dan field $\mid$ dependent).

Skor Deskripsi Data Hasil Belajar PKn

\begin{tabular}{|c|c|c|c|c|c|}
\hline \multirow{2}{*}{ Gaya Belajar } & \multicolumn{4}{|c|}{ Strategi Pembelajaran } & \multirow[b]{2}{*}{ Total } \\
\hline & \multicolumn{2}{|c|}{$\begin{array}{l}\text { Cooperative } \\
\text { Learning }\left(\mathrm{A}_{1}\right) \\
\end{array}$} & \multicolumn{2}{|c|}{ Ekspositori $\left(\mathrm{A}_{2}\right)$} & \\
\hline Field Independent $\left(\mathrm{B}_{1}\right)$ & $\begin{array}{l}\mathrm{n}_{1}= \\
\square \mathrm{X}_{1}= \\
\square \mathrm{X}_{1}^{2}= \\
\overline{\mathrm{X}}_{1}= \\
\left(\square \mathrm{X}_{1}\right)^{2}=\end{array}$ & $\begin{array}{l}11 \\
345 \\
10869 \\
31,36 \\
119025\end{array}$ & $\begin{array}{l}\mathrm{n}_{2}= \\
\square \mathrm{X}_{2}= \\
\square \mathrm{X}_{2}^{2}= \\
\overline{\mathrm{x}}_{2}= \\
\left(\square \mathrm{X}_{1}\right)^{2} \\
=\end{array}$ & $\begin{array}{l}11 \\
246 \\
5550 \\
22,36 \\
60516\end{array}$ & 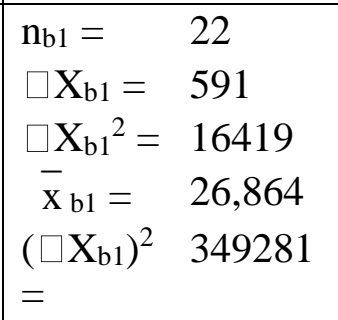 \\
\hline Field Dependent $\left(\mathrm{B}_{2}\right)$ & $\begin{array}{l}\mathrm{N}_{3}= \\
\square \mathrm{X}_{3}= \\
\square \mathrm{X}_{3}^{2}= \\
\overline{\mathrm{X}}_{3}= \\
\left(\square \mathrm{X}_{3}\right)^{2}=\end{array}$ & $\begin{array}{l}11 \\
228 \\
4780 \\
20,73 \\
51984\end{array}$ & $\begin{array}{l}\mathrm{N}_{4}= \\
\square \mathrm{X}_{4}= \\
\square \mathrm{X}_{4}{ }^{2}= \\
\overline{\mathrm{X}}_{4}= \\
\left(\square \mathrm{X}_{4}\right)^{2} \\
=\end{array}$ & $\begin{array}{l}11 \\
275 \\
7001 \\
25,00 \\
75625\end{array}$ & $\begin{array}{l}\mathrm{n}_{\mathrm{b} 2}=\quad 22 \\
\square \mathrm{X}_{\mathrm{b} 2}=503 \\
\square \mathrm{X}_{\mathrm{b} 2}^{2}=11781 \\
\overline{\mathrm{X}}_{\mathrm{b} 2}=22,864 \\
\left(\square \mathrm{X}_{\mathrm{b} 2}\right)^{2} \\
= \\
=\end{array}$ \\
\hline Total & $\begin{array}{l}\mathrm{n}_{\mathrm{k} 1}= \\
\square \mathrm{X}_{\mathrm{k} 1}= \\
\square \mathrm{X}_{\mathrm{k} 1}^{2}= \\
\overline{\mathrm{X}}_{\mathrm{k} 1}= \\
\left(\square \mathrm{X}_{\mathrm{k} 1}\right)^{2}=\end{array}$ & $\begin{array}{l}22 \\
573 \\
15649 \\
26,045 \\
328329\end{array}$ & $\begin{array}{l}\mathrm{n}_{\mathrm{k} 2}= \\
\square \mathrm{X}_{\mathrm{k} 2}=5 \\
\square \mathrm{X}_{\mathrm{k} 2}{ }^{2}=1 \\
\overline{\mathrm{X}}_{\mathrm{k} 2}= \\
\left(\square \mathrm{X}_{\mathrm{k} 2}\right)^{2} \\
=\end{array}$ & $\begin{array}{l}22 \\
521 \\
12551 \\
23,682 \\
271441\end{array}$ & $\begin{array}{ll}\mathrm{n}_{\mathrm{t}}= & 44 \\
\square \mathrm{X}_{\mathrm{t}}= & 1094 \\
\square \mathrm{X}_{\mathrm{t}}^{2}= & 28200 \\
\overline{\mathrm{X}}_{\mathrm{t}}= & 24,864 \\
\left(\square \mathrm{X}_{\mathrm{t}}\right)^{2}= & 1196836\end{array}$ \\
\hline
\end{tabular}

Rekapitulasi skor hasil belajar yang dihasilkan dalam penelitian ini dicantumkan pada tabel 4.1 berikut ini.

Tabel 4.1

Rekapitulasi Karakteristik Skor Hasil Belajar PKn

\begin{tabular}{|l|l|l|l|l|l|l|l|l|}
\hline Kelompok & $\begin{array}{l}\overline{\mathrm{X}} \\
\text { rata-rata }\end{array}$ & $\mathrm{M}_{\mathrm{o}}$ & $\mathrm{M}_{\mathrm{e}}$ & $\begin{array}{l}\text { Standar } \\
\text { Deviasi }\end{array}$ & Varians & $\begin{array}{l}\text { Skor } \\
\text { Min }\end{array}$ & $\begin{array}{l}\text { Skor } \\
\text { Max }\end{array}$ & Range \\
\hline $\mathrm{A}_{1}$ & 26,05 & 31,36 & 24,50 & 5,88 & 34,52 & 17 & 35 & 18 \\
\hline $\mathrm{A}_{2}$ & 23,68 & 24,36 & 23,88 & 3,18 & 10,13 & 19 & 30 & 11 \\
\hline $\mathrm{A}_{1} \mathrm{~B}_{1}$ & 31,36 & 30,83 & 31,25 & 2,20 & 4,85 & 28 & 35 & 7 \\
\hline $\mathrm{A}_{1} \mathrm{~B}_{2}$ & 20,73 & 19,50 & 20,25 & 2,33 & 5,42 & 17 & 24 & 7 \\
\hline $\mathrm{A}_{2} \mathrm{~B}_{1}$ & 22,36 & 21,83 & 22,25 & 2,20 & 4,85 & 19 & 26 & 7 \\
\hline $\mathrm{A}_{2} \mathrm{~B}_{2}$ & 25,00 & 26,50 & 25,65 & 3,55 & 12,60 & 19 & 30 & 11 \\
\hline
\end{tabular}



Dari tabel 4.1 tampak bahwa secara keseluruhan rata-rata skor hasil belajar PKn yang dihasilkan dengan strategi pembelajaran Cooperative Learning lebih tinggi dibandingkan strategi pembelajaran Ekspositori $\left(A_{1}>A_{2}\right)$. Demikian pula ratarata skor hasil belajar PKn peserta didik yang memiliki gaya belajar field independent dan mendapat strategi pembelajaran Cooperative Learning lebih tinggi daripada peserta didik yang mendapatkan strategi Eksporitori $\left(\mathrm{A}_{1} \mathrm{~B}_{1}>\right.$ $\left.\mathrm{A}_{2} \mathrm{~B}_{1}\right)$. Sebaliknya, peserta didik yang memiliki gaya belajar field dependent yang mendapat strategi pembelajaran Cooperative Learning memperoleh hasil belajar lebih rendah daripada peserta didik yang mendapatkan strategi pembelajaran Ekspositori $\left(\mathrm{A}_{1} \mathrm{~B}_{2}<\mathrm{A}_{2} \mathrm{~B}_{2}\right)$.

\section{Pengujian Persyaratan Analisis}

\section{Uji Normalitas Distribusi Populasi}

Pengujian normalitas data menggunakan taraf signifikansi $\alpha=0,05$. Rangkuman hasil perhitungan yaitu $\mathrm{A}_{1}, \mathrm{~A}_{2}$,

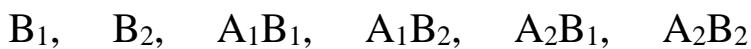
berdistribusi normal

\section{Uji Homogenitas Varians Populasi}

Hasil pengujian dengan uji Bartlett pada taraf signifikan $\alpha=0,05$ dan derajat bebas $=3$ ditunjukkan dalam tabel 4.3 dibawah ini:

Tabel 4.3

Rangkuman Hasil Uji Homogenitas

\begin{tabular}{|l|l|l|l|l|}
\hline $\mathrm{S}_{\text {gab }}{ }^{2}$ & $\mathrm{~B}$ & $\chi_{\mathrm{o}}^{2}$ & $\chi_{\mathrm{t}}^{2}$ & Kesimpulan \\
\hline 6,932 & 33,63 & 3,612 & 7,81 & Homogen \\
\hline
\end{tabular}

Hasil pengujian memberikan nilai $\chi^{2}$ hitung lebih kecil dibandingkan dengan nilai $\chi^{2}$ tabel, sehingga disimpulkan keempat kelompok data dalam penelitian ini berasal dari populasi yang variansinya homogen.

Tabel 4.5

Rangkuman Hasil Perhitungan ANAVA 2 Jalur (Rangkuman Hasil Analisis Varians untuk Melihat Pengaruh Strategi Pembelajaran dan Gaya Belajar Terhadap Hasil Belajar PKn)

\begin{tabular}{|c|c|c|c|c|c|c|}
\hline \multirow{2}{*}{ Sumber Variansi } & \multirow{2}{*}{$\mathrm{db}$} & \multirow{2}{*}{$\mathrm{JK}$} & \multirow{2}{*}{ RJK } & \multirow{2}{*}{ F hitung } & \multicolumn{2}{|c|}{$\mathrm{F}_{\text {tabel }}$} \\
\hline & & & & & 0,05 & 0,01 \\
\hline Strategi Pembelajaran & 1 & 61,45 & 61,45 & $8,866 * *$ & 4,08 & 7,31 \\
\hline Gaya Belajar & 1 & 176,00 & 176,00 & $25,390 * *$ & 4,08 & 7,31 \\
\hline Interaksi (A x B) & 1 & 484,45 & 484,45 & $69,889 * *$ & 4,08 & 7,31 \\
\hline Kekeliruan & 40 & 277,27 & 6,93 & & & \\
\hline Jumlah & 43 & 999,18 & & & & \\
\hline
\end{tabular}





\section{Pengujian Hipotesis Penelitian}

Pengujian hipotesis pertama, yang menyatakan: "Secara keseluruhan hasil belajar PKn pada peserta didik yang mendapatkan strategi pembelajaran Cooperative Learning lebih tinggi daripada peserta didik yang mendapatkan strategi pembelajaran Ekspositori”.

Dari hasil perhitungan dengan ANAVA 2 jalur diperoleh harga $F_{\text {hitung }}=$ 8,866 lebih besar dari $\mathrm{F}_{\text {tabel }}=7,31$ pada taraf nyata $\alpha=0,01\left(F_{\text {hitung }}=8,866>F_{\text {tabel }}\right.$ $(\alpha=0,01)=7,31)$, sehingga disimpulkan $\mathrm{H}_{0}$ ditolak. Ini membuktikan bahwa hasil belajar PKn peserta didik dengan strategi pembelajaran Cooperative Learning lebih tinggi dari kelompok peserta didik yang belajar dengan strategi pembelajaran Ekspositori.

Pengujian hipotesis kedua, yang menyatakan: "Hasil belajar PKn pada peserta didik yang memiliki gaya belajar field independent dan mendapatkan strategi pembelajaran Cooperative Learning lebih tinggi daripada peserta didik yang mendapatkan strategi belajar Ekspositori”.

Berdasarkan pengujian dengan uji Tukey terhadap $\left(\mathrm{A}_{1} \mathrm{~B}_{1}\right.$ banding $\left.\mathrm{A}_{2} \mathrm{~B}_{1}\right)$ diperoleh harga $Q_{\text {hitung }}=8,64$ lebih besar dibandingkan dengan $\mathrm{Q}_{\text {tabel }}=3,82$ pada taraf nyata $\alpha=0,05$. Dengan demikian hasil belajar PKn kelompok peserta didik yang belajar dengan strategi pembelajaran
Cooperative Learning lebih tinggi dibandingkan dengan kelompok peserta didik yang belajar dengan strategi pembelajaran Ekspositori pada kelompok peserta didik yang memiliki gaya belajar field independent.

Pengujian hipotesis ketiga, yang menyatakan : "Hasil belajar PKn pada peserta didik yang memiliki gaya belajar field dependent dan mendapat strategi pembelajaran Cooperative Learning lebih rendah daripada peserta didik yang mendapatkan strategi pembelajaran Ekspositori".

Dari hasil perhitungan dengan uji Tukey terhadap $\left(\mathrm{A}_{1} \mathrm{~B}_{2}\right.$ banding $\left.\mathrm{A}_{2} \mathrm{~B}_{2}\right)$ diperoleh harga $Q_{\text {hitung }}=-4,10$ lebih kecil dibandingkan dengan nilai $\mathrm{Q}_{\text {tabel }}=3,82$ pada taraf nyata $\alpha=0,05$. Dengan demikian hasil belajar PKn kelompok peserta didik yang belajar dengan strategi pembelajaran Cooperative Learning lebih rendah dibanding dengan kelompok peserta didik yang belajar dengan strategi pembelajaran Ekspositori pada kelompok peserta didik yang memiliki gaya belajar field dependent.

Pengujian hipotesis keempat, yang menyatakan : "Terdapat pengaruh interaksi antara strategi pembelajaran dan gaya belajar terhadap hasil belajar PKn".

Berdasarkan hasil pengujian pada analisis varians (ANAVA), diperoleh $\mathrm{F}_{\text {hitung }}$ $=69,889$ lebih besar dari $F_{\text {tabel }}=4,08$ pada taraf signifikan $\alpha=0,01\left(\mathrm{~F}_{\text {hitung }}=69,886>\right.$ 
Ftabel $(\alpha=0,01)=7,31) . \quad$ Ini membuktikan terdapat interaksi antara strategi pembelajaran dengan gaya belajar terhadap hasil belajar PKn. Untuk lebih jelasnya lihat gambar 4.7 di bawah ini.

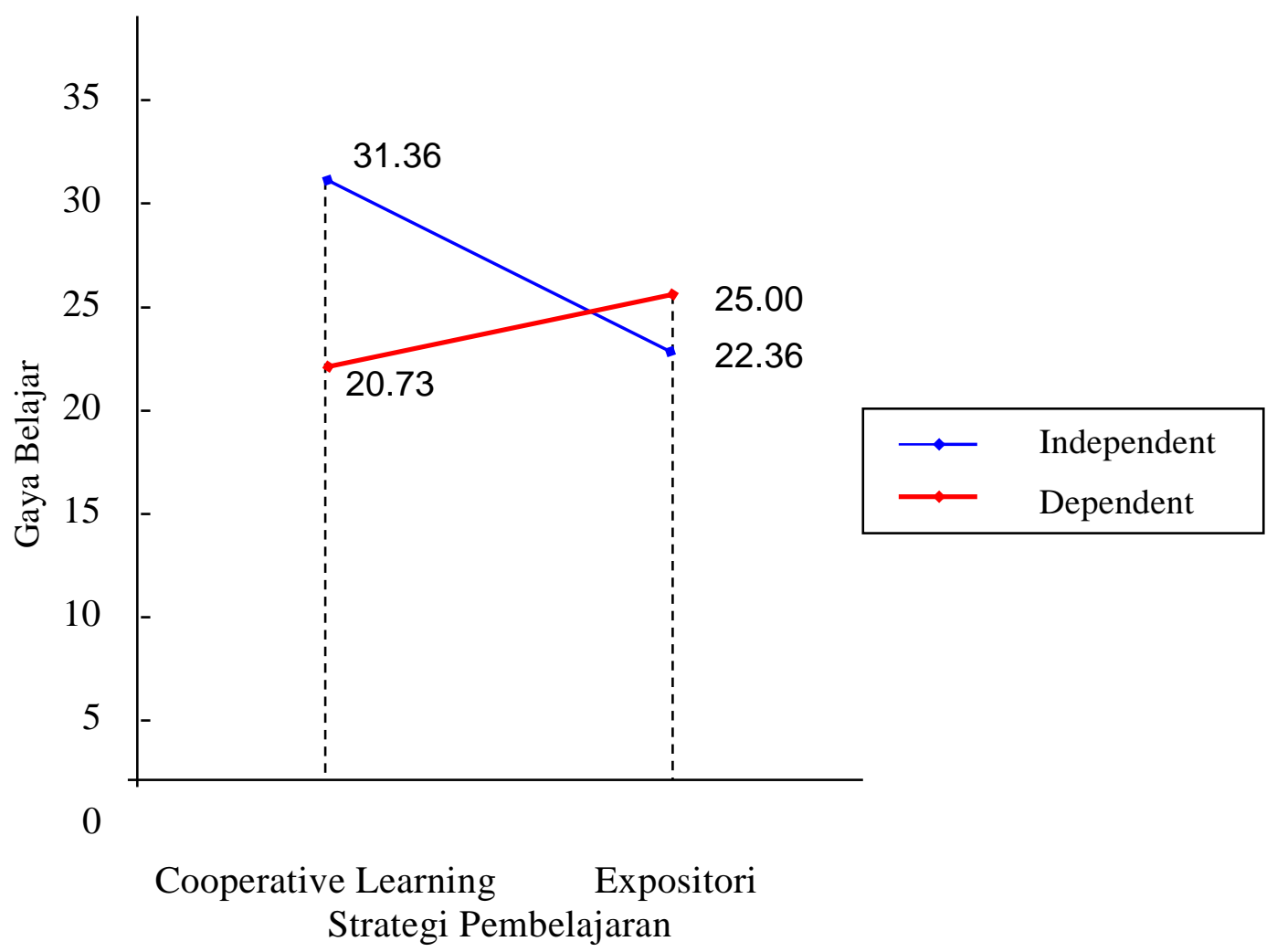

Gambar 4.1 Grafik Interaksi Strategi Pembelajaran dengan Gaya Belajar terhadap Hasil Belajar PKn

\section{KESIMPULAN}

Penelitian ini memberikan

kesimpulan sebagai berikut:

Pertama, secara keseluruhan penggunaan strategi pembelajaran Cooperative Learning memberikan hasil lebih tinggi terhadap hasil belajar PKn daripada penggunaan strategi pembelajaran Ekspositori. Dengan demikian secara keseluruhan untuk meningkatkan hasil belajar PKn diperlukan penggunaan strategi pembelajaran Cooperative Learning.
Kedua, bagi peserta didik yang memiliki gaya belajar field independent, penggunaan strategi pembelajaran Cooperative Learning dapat berpengaruh lebih tinggi terhadap hasil belajar PKn daripada penggunaan strategi pembelajaran Ekspositori. Dengan demikian, untuk meningkatkan hasil belajar PKn, bagi peserta didik yang memiliki gaya belajar field independent perlu menggunakan strategi pembelajaran Cooperative Learning. 
Ketiga, bagi peserta didik yang memiliki gaya belajar field dependent, penggunaan strategi pembelajaran Cooperative Learning dapat berpengaruh lebih rendah terhadap hasil belajar PKn daripada penggunaan strategi pembelajaran Ekspositori. Dengan demikian untuk meningkatkan hasil belajar PKn, bagi peserta didik yang memiliki gaya belajar field dependent perlu menggunakan strategi pembelajaran Ekspositori.

Keempat, terdapat interaksi antara penggunaan strategi pembelajaran dengan gaya belajar terhadap hasil belajar PKn. Dengan demikian dapat disimpulkan bahwa untuk meningkatkan hasil belajar PKn perlu diterapkan strategi pembelajaran Cooperative Learning dengan mempertimbangkan gaya belajar. Oleh karena itu peserta didik yang memiliki gaya belajar field independent perlu diberikan strategi pembelajaran Cooperative Learning, sedangkan yang memiliki gaya belajar field dependent perlu diberikan strategi pembelajaran Ekspositori.

\section{DAFTAR PUSTAKA}

Anderson, Lorin W. and David R. Kratwohl. Taxonomy for Learning Teaching and Assessing, A Revision of Bloom's Taxonomy of Education Objectives. New York: Addison Wesley Logman, Inc., 2001.
Dimyati dan Mudjiono. Belajar dan Pembelajaran. Jakarta: Tineka Cipta. 2002/

Gagne, RM; Lislei J Briggs and Walter W Wager. Principles of Instructional Design. New York: Holt Rinehart and Winston. 1999.

Gredler Margareth, E. Bell. Belajar dan Pembelajaran (terjemahan Munandir). Jakarta: Rajawali. 1991.

Lie, Anita. Cooperative Learning (Mempraktekkan Cooperative Learning di Ruang-ruang Kelas). Jakarta: Grasindo. 2002

Mayer, Richard E. Design Instruction for Constructivist Learning. Dalam Charles M. Reigeluth, Instructional Design Theories and Strategis. A New Paradigm of Instructional Theory. Volume II. Lawrence Associates, Publishers, Mahwah, New Jersey, London. 1999.

Miarso, Yusufhadi. Menyemai Benih Teknologi Pendidikan. Jakarta: Kencana. 2004.

Popham, James W. Teknik Mengajar Secara Sistematis. Solo: Rineka Cipta. 1992.

Reigeluth, Chrates M. InstructionalDesign Theories and Model: A New Paradigm of Instructional Theory. Hillsdale, New York: Lawrence Earlbaum. 1983.

Santoso, Soegeng. Problematik Pendidikan dan Cara Pemecahannya. Jakarta: Kreasi Pena Bading. 2000.

Seels, Barbara B and Richey, Rita C. Instructional Technology: The Definitions and Domain of The Field. Washington DC : Association for Educational Communication and Technology. 1994. 
Slavin, Robert E. Corporative Learning, Theory, Research and Practice. Boston, Allyn and Bacon: Second Edition. 1988

Sukmadinata, Nana S. Landasan Psikologi Proses Pendidikan. Bandung: PT Remaja Rosdakarya. 2003.

Suriasumantri, Jujun. Filafat Ilmu Sebuah Pengantar Populer. Jakarta: CV Muliasar. 2000.
Walter, Dick and Lau, Carey. The Systematic Design of Instruction. $3^{\text {rd }}$ Glenview, Illinois: Scott Foresman and Company. 1990.

Witkin, Herman. Education Psychology Theory and Practice. Ed. Robert E Slavin. Boston: Allyn and Bacon. 1981. 